\title{
Respiratory Arrest
}

National Cancer Institute

\section{Source}

National Cancer Institute. Respiratory Arrest. NCI Thesaurus. Code C101772.

Cessation of breathing function. 